\title{
Quatro atos para ler e agir: a obra de teatro na perspectiva de ensino dos (multi)letramentos
}

Four acts to read and to perform: the theatrical work on the perspective of (multi)literacies teaching

\section{Larissa Minuesa Pontes Marega* (D)}

larissamarega@hotmail.com

https://orcid.org/0000-0002-0278-2267

\author{
Everton Luis Paulino Vinha** (D) \\ profevertonpaulino@gmail.com \\ https://orcid.org/0000-0003-0158-627X
}

Zilda Gaspar Oliveira de Aquino*** (D)

ziaquino@usp.br

https://orcid.org/0000-0003-0432-7046

\section{Resumo}

Neste artigo, propomos proceder à correlação de teorias do ensino de literatura e dos multiletramentos, a partir de atividades em torno de uma obra teatral. Contextualizamos este estudo no bojo das discussões que analisam e que justificam a presença do livro na escola. A partir deste preâmbulo, buscamos embasamento teórico voltado ao letramento literário, à concepção de texto dramático e à multimodalidade. Metodologicamente, apresentamos a produção de uma sequência de ensino da leitura do texto A megera domada, de William Shakespeare, para o ano final do ensino fundamental. Os resultados apontam para a importância de procedermos a reflexões em torno do ensino de literatura, especificamente, da obra de teatro, sob uma perspectiva de leitura integral e multimodal, tendo em vista que estas podem promover a ampliação dos saberes e das competências aí implicadas.

Palavras-chave: Ensino de leitura; Letramento literário; Texto dramático; Multimodalidade; Sequência de ensino.

* Escola Magnus Domini, Maringá, SP, Brasil.

** Escola Magnus Domini, Maringá, SP, Brasil.

*** Universidade de São Paulo (USP), São Paulo, SP, Brasil.

\section{LINHA DÁGUA}




\begin{abstract}
In this article, we propose correlating theories of teaching literature with multiliteracies, based on activities around a theatrical work. We contextualize this study in the midst of the discussions that analyze and justify the presence of the book at school. From this preamble, we seek a theoretical basis focused on literary literacy, the concept of dramatic text and multimodality. Methodologically, we present the production of a teaching sequence for reading the text "A megera domada (The Taming of the Shrew)", by William Shakespeare, for the final year of elementary school. The results point to the importance of reflecting on the literature teaching, specifically theater, from a perspective of comprehensive and multimodal reading, considering that these can promote the expansion of knowledge and skills involved therein.
\end{abstract}

Keywords: Reading teaching; Literary literacy; Dramatic text; Multimodality; Teaching sequence.

\title{
Introdução
}

[A arte teatral é] múltipla, complexa e paradoxal, formada por duas substâncias contraditórias, porém intrínsecas, a literária e a cênica: ao mesmo tempo produção literária - texto dramático, e representação cênica concreta. Arte que se repete sem jamais ser a mesma. Real e imaginária. [...] Arte de um só - o autor, e de muitos - cenógrafos, atores, diretores; leitores, espectadores (MELLO, 2004, p. 90, grifos nossos).

Ao tratar da natureza multimodal do texto dramático e da sua aplicabilidade ao ensino de língua materna, Marega (2015) observa que o texto dramático, quando escolarizado, instaura-se como objeto de ensino desafiador, ao convocar três possibilidades distintas de tratamento do texto, a saber: 1 . corresponde a um texto narrativo, literário; 2 . ainda que seja classificado como texto narrativo, o texto dramático apresenta uma estrutura composicional diferenciada de outros textos da ordem do narrar; 3. a sua materialidade escrita convoca, necessariamente, a uma encenação.

Essa estudiosa investiu na terceira concepção, assumindo, portanto, a posição de que um espetáculo tem como ponto de partida um texto escrito, com diálogos, indicações cênicas, personagens, conflitos etc. A sua posição coaduna-se à de Peixoto (1986, p. 24) ao indicar que uma obra literária pode ser entendida como completa; "como texto teatral, entretanto, exige, para realizar-se integralmente, ser encenado".

Destacamos, ainda de Marega (2015), e com ela assumimos o pressuposto de que a leitura integral de uma obra de teatro na escola pode promover experiências leitoras instauradas, inicialmente, na imaginação do leitor, mas que podem também ser ampliadas, do ponto de vista dos saberes e das competências aí implicadas: do escritural ao multimodal. Assim, da tensão entre literatura e teatro, surge o presente estudo, que tem seu fio condutor na posição de Rosenfeld (1993, p. 21-22):

\section{LINHA DÁGUA}


Na literatura, são as palavras que medeiam o mundo imaginário. No teatro, são os atores/personagens (seres imaginários) que medeiam a palavra. Na literatura, a palavra é a fonte do homem (das personagens). No teatro, o homem é a fonte da palavra.

Com efeito, este artigo busca ampliar o trabalho de leitura do texto dramático, em sala de aula, a partir do encontro entre teorias advindas da Literatura, das Artes Cênicas e da Linguística Aplicada. Buscamos, assim, as posições de Cosson (2019 [2006]; 2020) a respeito do letramento literário e recorremos aos postulados de Colomer (2018 [2007]) para a legitimação da escola enquanto lugar social para a leitura de livros. Ancorados em estudos teatrais que discutem a reciprocidade entre texto dramático escrito e texto dramático oralizado, dentre eles Ryngaert (1995) e Ubersfeld (2010), apresentamos a teoria dos multiletramentos e da multimodalidade, inicialmente divulgada pelo Grupo de Nova Londres (COPE; KALANTZIS, 2000) e investida também pelas pesquisadoras brasileiras Rojo e Barbosa (2015), a fim de subsidiar a criação de atividades em torno de práticas leitoras de uma obra de teatro.

Na primeira seção, discutimos a presença da obra literária integral na escola e a sua abordagem no ensino. Na segunda, refletimos sobre as especificidades do texto dramático e a sua escolarização por um viés multimodal. Na terceira seção, à luz dos pressupostos citados, a leitura da obra selecionada, A megera domada, de William Shakespeare, traduzida e adaptada por Flavio de Souza (2013), encaminhou-nos para a criação de uma Sequência básica de letramento literário, organizada em quatro passos - Motivação, Introdução, Leitura e Interpretação - e composta por sete atividades voltadas para a mobilização multimodal do aluno-leitor.

No escopo da Linguística Aplicada e da Formação Docente, entendemos que este trabalho pode contribuir para o alargamento das possibilidades de ação do professor de língua portuguesa, ao oportunizar práticas de linguagem e de tratamento do texto literário engendradas na esfera teatral.

\section{Primeiro Ato: o ensino de literatura e o letramento literário}

De início, validamos a obra literária integral como objeto potencializador das aprendizagens escolares. Buscamos respaldo, para tanto, no estudo de Colomer (2018 [2007], p. 117), em Andar entre livros, a leitura literária na escola. A pesquisadora defende a presença e o uso do livro de literatura na sala de aula, uma vez que, para ela, o contato entre livros e crianças coloca-se como primeiro critério para a ativação da leitura escolar: "é imprescindível dar aos meninos e meninas a possibilidade de viver, por algum tempo, em um ambiente povoado de livros, no qual a relação entre as suas atividades e o uso da linguagem escrita seja constante e variada". Uma das suas premissas é a de que "ler se aprende lendo"; por isso, sustenta a ideia de que uma aula onde se lê e se fala sobre livros merece ser o centro do ensino da leitura literária. Nas palavras da autora,

\section{LINHA DÁGUA}


a escola deveria dedicar mais atenção à leitura de obras integrais (reduzindo o tempo dedicado a trabalhar as habilidades leitoras desintegradas), a aumentar a conexão entre leitura e escrita (invertendo os termos, inclusive) e a deixar de considerar o material de leitura como uma substância neutra denominada "textos" para aceitar que o tipo de livros lidos determinam [sic] o leitor que se forma (COLOMER, 2018 [2007], p.108, grifos nossos).

A leitura de livros, não de fragmentos, oferece-se como ocasião ajustada para falar ou escrever sobre eles, a partir deles ou segundo eles; no contexto escolar, obras são recitadas, dramatizadas ou lidas em voz alta, podem ser compartilhadas, comentadas, avaliadas. Para Colomer (2018 [2007]), a formação do leitor literário se dá exatamente nesse encontro e a partir desse contato direto com a obra, com o seu manuseio, de fato. Assim, experiências escolares literárias com a obra integral e material geram o domínio progressivo de competências leitoras e da capacidade interpretativa que a leitura de cada livro pode promover.

Cosson (2019 [2006]), em Letramento literário: teoria e prática, também analisa o ensino de literatura e as práticas de letramento que permitem o ato de ler a obra literária na escola. $\mathrm{O}$ autor disserta sobre a relação da literatura com o mundo e com o ambiente escolar, a fruição literária na aula de literatura, os critérios para a escolha de textos e os encaminhamentos para as suas leituras. Em seguida, propõe uma metodologia de ensino a partir de práticas reais. Essa análise é complementada por Paradigmas do ensino de literatura (2020), texto em que o autor sistematiza as principais características dos diferentes modos de ensinar literatura.

Reportamo-nos aos pressupostos de Cosson $(2019,2020)$ a fim de subsidiar nossa proposta de atividades de leitura de uma obra teatral, na aula de língua portuguesa. Ao questionar o efeito de prazer na leitura literária escolarizada, Cosson (2019) questiona três pressupostos sobre o aprendizado de literatura, segundo as suas investigações empíricas com alunos do ensino superior: o primeiro pressuposto é o de que "os livros falam por si mesmos ao leitor" (COSSON, 2019, p. 26); o segundo, o de que "ler é um ato solitário" (COSSON, 2019, p. 26); o terceiro, o de que a análise do texto literário "destruiria a magia e a beleza da obra" (COSSON, 2019, p. 28). Tais pressupostos fundamentam um pensamento de que estudar literatura é sinônimo de desprazer, uma vez que a leitura é tida como um ato autônomo, individual e instintivo.

No decorrer de seu escrito, o autor contesta cada um desses pressupostos. Para ele, a leitura não pode ser considerada autônoma, uma vez que está condicionada ao processo de escolarização do sujeito-leitor, processo esse que ensina a leitura individual, porém, extrapola os limites da fruição e do entretenimento. Também não pode ser compreendida como ação totalmente solitária, já que, em primeiro lugar, o diálogo entre autor-obra e leitor estabelecido é responsável por construir os sentidos da leitura e, em segundo lugar, a "interpretação é um ato solidário" (COSSON, 2019, p. 27), pois os sentidos dependem também da relação que se estabelece socialmente por meio da obra. Finaliza a sua contestação ao questionar a sacralização do texto literário, defendendo que a leitura objetiva abordar o texto sob diferentes perspectivas, não a fim de destituí-lo de sua aura cristalizada, mas de penetrá-la e de compreendê-la. Nas palavras do autor (2019, p. 29-30),

\section{LINHA DÁGUA}


[...] se quisermos formar leitores capazes de experienciar toda a força humanizadora da literatura, não basta apenas ler. Até porque, ao contrário do que acreditam os defensores da leitura simples, não existe tal coisa. Lemos da maneira como nos foi ensinado e a nossa capacidade de leitura depende, em grande parte, desse modo de ensinar, daquilo que nossa sociedade acredita ser objeto de leitura e assim por diante. A leitura simples é apenas a forma mais determinada de leitura, porque esconde sob a aparência de simplicidade todas as implicações contidas no ato de ler e de ser letrado. É justamente para ir além da simples leitura que o letramento literário é fundamental no processo educativo.

Após tratar do ensino de literatura e, em particular, do ensino da obra literária, Cosson (2020) investiga quais são os modos de ensiná-la, propondo o conceito de paradigma, isto é, conjunto de "saberes e práticas, conceitos e técnicas, questionamentos e exemplos, objetos e termos usados para descrevê-los dentro de uma determinada área do conhecimento." (COSSON, 2020, p. 7). Elencam-se seis paradigmas: Moral-gramatical e Histórico-nacional (com tendências mais tradicionais); Analítico-textual, Social-identitário, Formação de leitor e Letramento literário (com tendências mais contemporâneas).

Nas discussões propostas por esse estudioso, os sentidos que se instauram no ensino de literatura ora se complementam, ora se distinguem. Enquanto os paradigmas Moral-gramatical e Histórico-nacional privilegiam leituras instrumentalizadas, fechadas em recortes de textos literários e objetivos que não a própria literatura, o paradigma Analítico-textual estabelece um objetivo e uma disciplinaridade própria, mas recorre à análise do texto pelo texto, limitada à identificação e à apreciação estética. Todos esses, contudo, valorizam a leitura do texto escrito e a escolarização com o foco na reprodução de compreensões já existentes ou de modelos de análise. Em contrapartida, os paradigmas Social-identitário e Formação do leitor transferem os sentidos da leitura do texto para o leitor, no que se refere à identificação com o texto ou à fruição que se faz dele. Em ambos os casos, a obra literária e a própria literatura ganham valores que prescindem da obra.

O paradigma Letramento literário, conceito cunhado por Graça Paulino e sistematizado por Cosson, é definido, em parceria, como o "processo de apropriação da literatura enquanto construção literária de sentidos" (PAULINO; COSSON, 2009, p. 67 apud COSSON, 2020, p. 195). A literatura é aqui compreendida em três instâncias: a das obras, a da escrita e a da leitura. Essas três instâncias aliadas - obra, escrita e leitura - perfazem o que Cosson (2020, p. 201) entende por literatura: “[...] linguagem que se apresenta como um repertório de textos e práticas de produção e interpretação, pelos quais simbolizamos nas palavras e pelas palavras a nós e o mundo que vivemos.".

O valor da literatura, nessa acepção, reside na construção simultânea de efeitos que se estabelecem entre obra e leitor, conferindo ao ensino o propósito de desenvolver, no aluno, a competência para significar a leitura do literário. Essa competência é denominada por Cosson (2020) Leitura da linguagem literária, a qual engloba o ato de ler a partir de três repertórios requeridos para o seu desenvolvimento, a saber: o do texto, reconhecendo as obras literárias; o do intertexto, relacionando essas obras; e o do contexto, simbolizando a leitura a partir das

\section{LINHA D'́GUA}


condições de produção e de leitura externas à sua materialidade. Em outras palavras, desenvolve-se a competência do aluno de ler o texto literário nos seus traços estilísticos, de relacioná-lo com outros textos e de simbolizar a prática de leitura por meio do contexto de produção e de leitura da obra.

A metodologia de ensino sustentada pelo paradigma do Letramento literário é apresentada em três etapas, quais sejam: Antecipação, Decifração e Interpretação (COSSON, 2019, p. 40). Essas correspondem, respectivamente, às estações que o autor propõe posteriormente (COSSON, 2020, p. 212-214): encontro pessoal do aluno com a obra, leitura responsiva e leitura como prática interpretativa. A primeira etapa relaciona-se às práticas que antecedem à leitura do texto literário propriamente dito, lendo-se informações disponíveis em paratextos, por exemplo. A leitura efetiva da materialidade linguística ocorre em um segundo momento e varia de acordo com o perfil ou nível do leitor. Na terceira e última etapa, cabe ao leitor processar a sua leitura, interpretando o texto em um "diálogo que envolve autor, leitor e comunidade", a depender "do que escreveu o autor, do que leu o leitor e das convenções que regulam a leitura" (COSSON, 2019, p. 41).

Desse modo, a prática do Letramento literário envolve um olhar múltiplo para o ensino de leitura. No contexto escolar, o autor propõe uma Sequência básica de Letramento literário, instituindo quatro passos que orientam as práticas de ensino e a formação literária do aluno. São eles: Motivação, Introdução, Leitura e Interpretação.

Na Motivação, prepara-se o aluno para o texto literário sem, no entanto, ignorá-los (obra e aluno). Desse modo, o autor sugere atividades que criem expectativas no alunado, mas com a consciência da influência que tais expectativas podem criar no leitor e na leitura da obra.

Em seguida, na Introdução, apresentam-se autor e obra. Neste passo, de posse da obra física, aproveitam-se os elementos paratextuais (capa, contracapa, orelha etc.) de maneira a permitir a ação do aluno no levantamento e na análise dessas informações.

O passo da Leitura determina que ela pode ser guiada pelo professor. Assim, textos de curta extensão podem ser lidos integralmente em sala de aula; por outro lado, o autor sugere que textos de maior extensão sejam lidos pelos alunos em casa ou em outro espaço do ambiente escolar. Assim, nesta etapa, o aluno deve ler a obra completa sem, no entanto, que isso seja feito durante as aulas. $\mathrm{Na}$ aula em si, cabe ao professor acordar essas dinâmicas e intervir no processo, acompanhando a leitura remota, diagnosticando-a por meio de atividades variadas e, até mesmo, relacionando-a com outros textos.

No último passo, a Interpretação se dá pelo entrecruzamento de enunciados da própria obra e das inferências que o leitor faz ao lê-los. A construção de sentidos ocorre, conforme assegura Cosson (2019), na tríade autor-leitor-comunidade. A Interpretação se concretiza em dois momentos: no Momento interior e no Momento externo. O Momento interior diz respeito à confluência do que foi mobilizado até então: por parte da escola, as atividades desenvolvidas na Motivação, na Introdução e na Leitura são aquelas que interferem na apreensão da obra pelo

\section{LINHA DÁGUA}


aluno; além dessas, as vivências e as experiências pessoais e não escolares do aluno também influenciam os sentidos que serão apreendidos, o que caracteriza a interpretação como um ato social. O Momento externo é a interpretação realizada em comunidade com alunos e demais sujeitos no ambiente escolar. É nesse momento que os sentidos apreendidos no Momento interior se ampliam, quando há a troca de ideias no coletivo, buscando, de fato, externalizar as leituras realizadas.

Os quatro passos do Letramento literário sugerem a Sequência básica de práticas docentes para o ensino de literatura, buscando um ensino que aborde os repertórios necessários à formação de uma competência leitora. Posto que buscamos ampliar a acepção apresentada pelo autor de modo a ressignificar o ensino de leitura de peças teatrais na aula de língua portuguesa, apresentamos, a seguir, os aportes teóricos acerca do texto dramático e da sua natureza multimodal que nos darão subsídios para alcançar essa proposta.

\section{Segundo Ato: o texto dramático e a multimodalidade}

Do ponto de vista teórico, elegemos o texto dramático na sua dupla acepção: texto escrito que projeta um dizer-fazer, e texto oralizado (representação cênica), que opera com esse dizer-fazer. Vários estudiosos discorrem sobre a interdependência existente entre a estrutura escritural do texto dramático e a sua possibilidade para a cena; dentre eles, destacamos Ubersfeld (2010), para quem a peça escrita para o teatro corresponde à composição de responsabilidade do dramaturgo, a ser executada por atores, e também ao conjunto de sinais, signos e símbolos - verbais e não verbais - vocalizados durante a realização de um espetáculo - em outros termos, àquilo que os atores dizem e fazem, palavras e ações.

Nossa posição é a de que o texto dramático apresenta desdobramentos enunciativos, característica que, a nosso ver, mobiliza o papel do leitor e da sua interação com a obra de teatro. $\mathrm{Na}$ sua composição estrutural, o texto dramático comporta diálogo e descrição. $\mathrm{Na}$ sequência, citamos as três possibilidades de interlocução, inserindo, nesse contexto, a classificação dos tipos de rubricas e a definição de aparte. A partir dessa posição, o nosso investimento em torno de uma proposta de ensino de leitura de uma peça de teatro concretizase, ao convocarmos os estudos dos multiletramentos e da multimodalidade para nos subsidiar.

De fato, a materialidade escrita do texto dramático constrói-se a partir da alternância de sequências conversacionais (diálogos), que são mais destinadas a serem faladas do que lidas, e de sequências descritivas (rubricas ou didascálias), mais destinadas a serem lidas do que faladas. Tais sequências admitem três interlocuções prováveis para o texto dramático: 1 . dramaturgo escreve para um leitor-literário; 2. dramaturgo direciona o texto para um leitorator; 3. dramaturgo direciona o texto para um espectador implícito.

Tomamos, pois, um livro de teatro qualquer: a sua composição estrutural articula diálogo e descrição, alternando-se de modo heterogêneo. Diante desse entendimento e para

\section{LINHA D'ÁGUA}


explicitar a primeira instância de interlocução, lançamos mão da sua faceta literária, que prevê, de antemão, um autor-dramaturgo, responsável por direcionar o seu texto para um leitorliterário; este, consequentemente, terá acesso à história apenas por meio da materialidade textual e todo o imaginário da ação das personagens passa a ser interiorizado na sua mente. Para Mello (2004, p. 94), "trata-se de uma enunciação entre um EU-comunicante e um TUinterpretante, entre um sujeito autor e o leitor - ambos sujeitos empíricos -, e a obra como veículo de interação entre eles".

Quando assumimos o texto dramático no bojo da esfera teatral, é consentido afirmar que aquele responsável pela escrita (o dramaturgo) também destina o seu texto a um possível leitorator, que necessitará buscar, para execução da cena, marcações explícitas no texto escrito. A presença das didascálias (ou rubricas), por exemplo, ratifica essa segunda possibilidade de interlocução.

Helbo (1989) classifica as rubricas conforme a informação que apresentam e de acordo com o tipo de interlocutor a que se destinam: pensadas para o ator, pensadas para a ação, pensadas para o leitor e pensadas para o espectador implícito. As rubricas de interpretação revelam o sentimento das personagens e promovem a sustentação do clima instaurado no diálogo, indicando, também, como os atores devem falar; já as rubricas cênicas indicam o onde, isto é, a posição dos objetos da cena e a configuração do cenário, marcações igualmente válidas para cenógrafos, encenadores, contrarregras e demais envolvidos na produção de um espetáculo; as rubricas de ação ou movimento exploram o quê as personagens devem fazer e, novamente, auxiliam os atores ao modo de agir, gesticular, deslocar-se, dirigir o olhar, entrar e sair de cena.

Conforme assinala Ryngaert (1995), essas sequências textuais descritivas (rubricas) configuram o principal material da representação cênica: não se destinam a ser pronunciadas no palco, mas ajudam o leitor a compreender e a imaginar a ação e as personagens e são verdadeiramente úteis aos participantes de uma peça teatral durante os ensaios.

A terceira instância de interlocução requer pensarmos em uma projeção maior do texto dramático, direcionando-o a outro tipo de leitor, o espectador implícito. Chacra (2010, p. 55) assegura que não se pode falar em teatro "se não houver alguém em cena que faça alguma coisa e alguém que assista. Entre um e outro, algo os deve unir. Esse algo é aquilo que se pode chamar 'texto teatral'.".

No texto dramático escrito, essa interação é sinalizada por meio dos apartes fragmentos em que o autor escreve algo para uma personagem segredar apenas ao público, em tom de confidência. De acordo com Pavis (2008, p. 21), o aparte assinala a real intenção ou opinião do caráter da personagem, de modo que, na representação cênica, o espectador saiba a que se ater em relação àquela situação; este discurso pode, inclusive, ser acompanhado por "um jogo cênico capaz de torná-lo verossímil (afastamento do ator, mudança de entonação, olhar fixo na sala).”.

\section{LINHA D'́GUA}


$\mathrm{Na}$ hipótese da concretização do texto dramático como representação cênica, o ator estabelece para si outras duas possibilidades de interlocução: "ao mesmo tempo em que é ele próprio, é também 'o outro' (a personagem); ao mesmo tempo em que se comunica com os seus colegas-personagens, também se comunica com o público." (CHACRA, 2010, p. 73).

Depreendemos, assim, que, por ser vocacionado para o palco, o texto dramático carrega marcas da sua teatralidade. A função atribuída às rubricas corrobora essa assertiva, pois revela uma característica própria da ordem do escritural que aponta para o multimodal. Nessa acepção, entendemos que, respaldados pelos pressupostos teóricos dos multiletramentos $\mathrm{e}$ da multimodalidade, seja viável o trabalho com uma obra de teatro na escola, por possibilitar a experimentação de múltiplas semioses.

A pertinência dos estudos que preconizam os caminhos multimodais para a produção dos sentidos decorre da compreensão de que a palavra escrita deixa de ser a principal forma de produzir sentidos e passa a fazer parte de um conjunto que inclui, além de textos verbais, outras semioses. As pesquisas que preconizam os multi, por assim dizer, colocam em xeque a escrita como única modalidade de acesso ao conhecimento.

A produção dos estudos linguísticos sob a perspectiva dos multiletramentos, divulgada amplamente pelo chamado Grupo de Nova Londres (GNL) (COPE; KALANTZIS, 2000), caminha para a complexidade da reflexão sobre as múltiplas semioses (verbal, verbo-visual, corporal, sonora, entre outras) que constituem os textos da contemporaneidade. Em solo nacional, a pesquisadora Roxane Rojo, em parceria com outros estudiosos, tem discutido questões dessa ordem, que envolvem textos multimodais e a sua relação com a escola, a mídia, a cultura e a sociedade. $\mathrm{O}$ texto multimodal ou multissemiótico é aquele que recorre

a mais de uma modalidade de linguagem ou a mais de um sistema de signos ou símbolos (semioses) em sua composição. Língua oral e escrita (modalidade verbal), linguagem corporal (gestualidade, danças, performances, vestimentas modalidade gestual), áudio (música e outros sons não verbais - modalidade sonora) e imagens estáticas e em movimento (fotos, ilustrações, grafismos, vídeos, animações - modalidades visuais) (ROJO; BARBOSA, 2015, p. 108).

Uma das ideias-chave que direciona a noção dos multiletramentos é a crescente complexidade e a inter-relação dos diferentes modos de significar. Conforme assegura Jewitt (2008), os estudos multimodais tratam de configurações que dizem respeito à imagem, ao gesto, ao olhar, à postura corporal, ao som, à escrita, à música, ao discurso etc.: "Na perspectiva multimodal, imagem, ação e, assim por diante, são referidos como modos, como conjuntos organizados de recursos semióticos para construção de significados"” (JEWITT, 2008, p. 246).

1 Tradução nossa de: "From a multimodal perspective, image, action, and so forth are referred to as modes, as organized sets of semiotic resources for meaning making".

\section{LINHA DÁGUA}


Se os modos de compreensão e interação da sociedade contemporânea são multissemióticos, os letramentos também podem ser múltiplos. Conforme observa Kleiman (2014, p. 81), os pesquisadores do GNL

[...] advogam por uma concepção de letramento muito mais ampla do que aquela que em geral embasa o trabalho escolar, e propõem o ensino dos multiletramentos, isto é, da inclusão no currículo de todas as formas de representar significados dos diferentes sistemas semióticos - linguístico, visual, sonoro ou auditivo, espacial e gestual - inter-relacionados no texto multimodal contemporâneo.

Nesse sentido, assumimos o estudo (leitura, produção escrita, produção oral, produção gestual) do texto dramático na aula de língua portuguesa como um trabalho que envolve, necessariamente, a noção de multiletramento. Assim, passamos ao tratamento multimodal do texto dramático como fio condutor para a criação de uma Sequência básica de Letramento literário, tendo por base a obra A megera domada (2013).

\section{Terceiro Ato: uma proposta de sequência básica de ensino de (multi)letramento literário da peça $A$ megera domada}

Nossa experiência no ensino de língua portuguesa permite-nos afirmar que uma das vias de acesso do aluno a uma obra de teatro é a escola. O texto dramático inscreve-se, comumente, em fragmentos publicados nos livros didáticos, previstos para o oitavo e o nono anos. Essa realidade, a nosso ver, é efeito da sua escolarização, já que textos dramáticos pertencentes ao cânone literário são, via de regra, extensos e, dificilmente, teriam a sua publicação na íntegra.

A escolha pela proposta de ensino de leitura da obra A megera domada (2013), texto de William Shakespeare traduzido e adaptado por Flavio de Souza e ilustrado por Anna Anjos, parte, em primeira instância, deste intuito: o de promover o trabalho com o livro de teatro na aula de língua portuguesa.

Em segunda instância, a seleção desta comédia justifica-se pela complexidade e pela riqueza dos elementos que a edição escolhida apresenta. Dividida em cinco atos, compõe-se também por uma série de paratextos: aqueles que precedem o texto, Muitas megeras, em que o tradutor explica e justifica algumas de suas escolhas de adaptação, e $A$ história e a estória, uma síntese dos aspectos históricos e narrativos da peça; e aqueles que se seguem ao texto, $A$ megera domada e o Teatro elisabetano, em que se explicam fatores contextuais da peça e sua sobrevivência até a atualidade, além de breves biografias do autor, do tradutor e da ilustradora.

Um dado significativo desta adaptação é o fato de o tradutor ter reposicionado a personagem Trânio, criado de Lucêncio, para a função de narrar as ações das personagens, explicando e comentando toda a trama. A personagem fala constante e diretamente com uma provável plateia, apresentando, assim, a peça:

Meu nome é Trânio e vou ser seu guia nesta visita. Bem, o bom do teatro é que quem está aqui prega uma peça em quem está aí. Nós aqui fingimos que estamos

\section{LINHA DÁGUA}


em outro tempo e outro lugar, e vocês aí fingem que acreditam. Vez por outra alguém pode atravessar (indica) a quarta parede e falar direto com os espectadores. É o que estou fazendo neste momento, para lhes contar uma história hilária [...] (SHAKESPEARE, 2013, p. 22).

Neste momento, o autor-dramaturgo decide vocalizar, por intermédio da personagem Trânio, aquilo que denominamos, na linguagem teatral, aparte. Trânio soma a voz do autor do texto dramático à sua voz e convida, explicitamente, o aluno-leitor a uma experiência teatral, transpondo-o para o estatuto de espectador implícito e redefinindo-o, assim, como público, cúmplice ativo da estória. A nosso ver, essa interlocução promove, já de início, uma interação entre o leitor e a obra especificamente.

Para a proposta de leitura da obra A megera domada (2013), a Sequência que propomos nesta seção segue os quatro passos de Casson (2019), Motivação, Introdução, Leitura e Interpretação; porém, em cada um desses passos, sugerimos uma ou mais atividades que exploram os saberes escritural e multimodal.

Na Motivação, propomos o jogo teatral intitulado Blablação - intérprete, mobilizando as funções de aluno-jogador e de aluno-espectador. Na Introdução, a atividade sugere um aluno-pesquisador do contexto histórico do autor e da peça. Na Leitura, cada ato do texto teatral é lido de forma multimodal, por meio de leitura dramática, pesquisa, construção da personagem, produção de figurino, direção e encenação de uma cena e escrita de outra. Nesse sentido, o aluno-leitor assume os lugares de aluno-orador, aluno-ator, aluno-figurinista, alunocenógrafo, aluno-contrarregra, aluno-sonoplasta, aluno-diretor, aluno-dramaturgo. $\mathrm{Na}$ Interpretação, o aluno-leitor passa a figurar como aluno-produtor, expandindo a sua leitura do texto na produção de cartazes de divulgação de uma encenação contemporânea da peça.

É válido ressaltar que a proposição dessas categorias emerge da obra escolhida. Ao mencionarmos cada atividade, explicamos também as motivações teóricas e metodológicas que orientam a possibilidade da sua aplicação em sala de aula.

\subsection{Motivação}

Estudos voltados para os jogos teatrais têm revelado o caráter insubstituível desse método também nas aprendizagens escolares; destacamos aqui o investimento de Spolin (2010). Conforme entendemos, os jogos constituem o primeiro passo para a aprendizagem da linguagem teatral e podem ser utilizados como atividades pedagógicas que auxiliam no domínio e na fluência da comunicabilidade, possibilitando o desenvolvimento de competências expressivas e promovendo a consciência de grupo. Desse modo, em nossa Sequência, a atividade proposta para a Motivação configura-se como sugerimos no Quadro 1: 
Quadro 1. Atividade de Motivação

\section{JOGO TEATRAL: BLABLAÇÃOO ${ }^{2}-$ INTÉRPRETE}

Distribuir os alunos em trios. Enquanto um trio joga, os demais alunos compõem a plateia. Explicar a dinâmica do jogo: dispostos lado a lado, o jogador 1, à esquerda das vistas da plateia, pronuncia uma frase em blablação para iniciar o diálogo; o jogador 2, localizado ao centro, precisa traduzir, em língua portuguesa, ao seu modo, o que foi dito pelo jogador 1, direcionando sua produção oral para o jogador 3; este, por sua vez, localizado à direita das vistas da plateia, compreende o que foi traduzido pelo jogador 2 e prossegue a interação, respondendo ao jogador 1, também em blablação, contando com a tradução do jogador 2. O diálogo se desenrola a partir desta premissa: somente o jogador 2 é capaz de entender ambas as linguagens empregadas no jogo pelos jogadores 1 e 3 , ele é o intérprete, responsável por traduzir esse diálogo à plateia. Para ambientar o jogo e convidar a participação da plateia, os alunos podem definir onde os jogadores 1 e 3 estão (cenário/ambiente), quem são eles (ou qual é relação entre eles) e $o$ quê pode motivar a ação da cena (assunto).

Fonte: Adaptado de Spolin (2010, p.189).

O jogo constrói-se na relação estabelecida entre os três jogadores que são levados à cena, o aluno-jogador interage com outro(s) aluno(s)-jogador(es) e a totalidade dessas falas (e das ações aí implicadas) promovem uma interação, também, com a plateia. Chamamos este último conjunto instaurado pela manifestação teatral, no contexto de sala de aula, de alunoespectador.

Ao ser realizado na aula de língua portuguesa, o jogo teatral Blablação - intérprete promove a experimentação da oralidade, utilizando-se, para tanto, uma língua inventada e outras semioses: gestos, direcionamento de olhar, movimentação corporal, por meio da improvisação de uma cena.

Pautados na tríade que sustenta o fazer teatral, ator-texto-público, selecionamos esse jogo, em particular, para compor a Motivação da leitura da obra A megera domada (2013) pois, na Cena I, do Terceiro Ato, a personagem Lucêncio (disfarçado de professor de literatura, Câmbio) conversa com sua pretendente Bianca e estabelece um jogo cênico análogo:

BIANCA - Onde estávamos?

LUCÊNCIO - Lendo Ovídio em Latim: Hic ibat Simois, hic est Sigeia tellus, Hic steterat Priami regia celsa senis.

BIANCA - Traduza, por favor.

LUCÊNCIO - "Hic ibat", como eu disse antes, "Simois", eu sou Lucêncio, "hic est", filho de Vicêncio, de Pisa, "Sigela tellus", disfarçado de professor para declarar todo o meu amor por você, "Hic steterat", e aquele que diz que é Lucêncio, "Priami", na verdade é meu

2 De acordo com Spolin (2010, p. 179), “a blablação é a substituição de palavras por sons. Não deve ser confundida com linguagem confusa, em que palavras são invertidas ou mal pronunciadas [...]. O significado de um som em blablação será compreendido somente quando o jogador se comunicar por ações e expressões ou tom de voz".

\section{LINHA DÁGUA}


criado Trânio, "regia", fingindo ser eu, "celsa senis", para que eu possa enganar e vencer a concorrência.

HORTÊNSIO - Pronto, meu instrumento está afinado.

BIANCA - Será? Acho que não. Afine melhor!

LUCÊNCIO - Se é que você sabe fazer isso. (SHAKESPEARE, 2013, p. 61).

Na cena apresentada, as personagens buscam um mecanismo de interação verbal para despistar o outro candidato a marido da mocinha. Ocorre que o conteúdo, bem como a extensão do texto proferido por Lucêncio, em latim, não correspondem ao que é traduzido, por ele, em português. A comicidade inerente a esse diálogo reporta-nos ao que pode ser evocado, também, com a possibilidade de aplicação do jogo Blablação - intérprete.

Tal jogo atende à função de motivar os alunos à leitura de uma obra de teatro, pois cria expectativas acerca da linguagem teatral e do teor cômico de uma encenação, justificando-se, assim, sua leitura. Essa atividade não tem o propósito de introduzir o reconhecimento do texto, especificamente, pois este será o próximo passo de nossa Sequência.

\subsection{Introdução}

Neste passo, buscamos a apresentação do autor e da obra literária aos alunos via pesquisa. Entre as classificações que Gil (2002 [1987]) levanta para os tipos de pesquisa, a pesquisa bibliográfica é aquela que se vale de fontes de referência para a sua elaboração, inclusive de livros de leitura corrente como as obras literárias.

Para a Introdução, buscamos promover o contato inicial do aluno com o contexto histórico de produção da obra, a fim de compreender a classificação do gênero de $A$ megera domada (2013) e as condições de produção que levaram à sua escritura, conforme descrevemos no Quadro 2, a seguir:

Quadro 2. Atividade de Introdução

\section{PESQUISA BIBLIOGRÁFICA}

Convidar os alunos a fazer uma pesquisa bibliográfica na biblioteca da escola (ou na internet), a fim de levantar informações sobre as obras de William Shakespeare. Nessas obras, orientar a identificação de dados acerca do autor e do texto na contracapa, nas orelhas e nos paratextos que acompanham o livro, por meio de questões como: "Qual é a caracterização que se faz sobre o autor (romancista, contista, poeta, dramaturgo etc.)? Quais informações sobre ele são levantadas (idade, nacionalidade, posição social, vida profissional, vida social, morte)? A qual gênero literário a obra pertence (romance, crônica, conto, poema, texto teatral - auto, comédia ou tragédia)?". Elencar, coletivamente, os resultados em busca de um mapeamento do autor e de suas obras. A partir da pesquisa, promover algumas inferências: que gênero será lido, de que tipo é a peça, como esse texto difere de uma narrativa ou de um poema, como será o seu vocabulário, que época será retratada, quais temas serão abordados, quais serão as personagens, de que forma esses temas serão desenvolvidos nas e pelas personagens.

\section{LINHA DÁGUA}


Em seguida, confrontar esses resultados com os paratextos da edição: quem foi o autor, qual é a sua relevância literária, qual é o gênero a ser lido, quais temas serão abordados, em que época está ambientada a estória, quais são os possíveis reflexos históricos nela e em sua abordagem temática via personagens.

Fonte: Elaborado pelos autores.

Cosson (2019) assegura que, toda vez que se lê um livro, está-se também lendo o seu contexto; por essa razão, classifica diversos tipos de contextos sem, no entanto, limitá-los. No nosso caso, sugerimos a abordagem do contexto histórico, buscando verificar de que modo, em certas obras, determinados conceitos são fundamentais. Para tanto, deslocamos a contextualização do passo da Interpretação por não termos o objetivo, ainda, de estabelecer a relação do conteúdo do texto com suas condições externas de elaboração. O que se pretende aqui é a Introdução da obra de teatro, via pesquisa em torno do autor.

$\mathrm{O}$ aluno assume, nesta etapa, a função de pesquisador, orientado pelo professor a descobrir aquelas informações que lhe permitiriam uma compreensão inicial da leitura que está por vir e o conhecimento de quem lerão, isto é, de como é possível diferenciar o contexto de leitura do agora da época em que a obra foi publicada (século XVI). Trata-se de uma preparação para a leitura.

É válido mencionar que, ao relacionar a atividade de pesquisa àquilo que a adaptação do texto dramático escolhido apresenta, seguimos duas orientações de Cosson (2019, p. 60), a saber: a Introdução não se configura como a exposição da biografia do autor, mas como a compreensão ativa das informações gerais da sua produção que permeiam a leitura de um dos seus textos, criando expectativas para a leitura no aluno-leitor-pesquisador; a análise dos elementos paratextuais que compõem a obra introduzem-na fisicamente e integralmente ao aluno-leitor.

\subsection{Leitura}

O passo da Leitura foi dividido em cinco atividades, cada uma dedicada à leitura de um dos cinco atos de $A$ megera domada (2013). A leitura prévia de cada ato é sugerida e depois retomada em sala de aula; ao segmentar a leitura, lê-se a obra em partes, o que permite a intervenção e a ação guiada do professor. Neste processo, convidamos o professor a analisar e a diagnosticar diversas habilidades do aluno-leitor: a de análise linguística, a de leitura, a de oralização do texto, a de dramatização, a de apreensão dos elementos do texto dramático, a de assimilação dos sentidos explícitos e implícitos da obra teatral.

A leitura do Ato I desenvolve-se a partir da leitura dramática, comum em exercícios do universo teatral - ação particularizada de ler, que privilegia uma aproximação dos atores com a materialidade linguística, nos seus primeiros contatos com a produção oral do texto escrito. Conforme assegura Ryngaert (1995, p. 50):

\section{LINHA DÁGUA}


Entre as instruções mecânicas, experimentam-se todas as oposições de ritmo, de articulação, de nível sonoro: lê-se muito depressa ou muito devagar, berra-se, sussurra-se ou salmodia-se; procura-se terminar o mais rápido possível ou, pelo contrário, saborear todas as harmonias e asperezas; tentam-se acentos e acentuações $[\ldots]$.

A atividade intitulada Leitura Dramática, desenvolvida para a leitura do Ato I da peça A megera domada (2013), apoia-se nessa ideia. No Quadro 3, a seguir, arrolamos inúmeras formas de oralizar esse texto.

Quadro 3. Atividade de Leitura do Ato I

\section{LEITURA DRAMÁTICA}

Com a obra em mãos, solicitar que os alunos se sentem em círculo. Propor a leitura dramática das duas cenas que compõem o Ato I da peça, convidando-os a assumirem as falas das personagens, atribuindo a elas modos de dizer peculiares. Como sugestão, apresentamos algumas possibilidades ${ }^{3}$ :

- Leitura branca: leitura sem compromisso com a entonação, destituída de dramatização, recorre à mínima expressividade, não obedece a sinais de pontuação.

- Leitura exagerada: leitura que valoriza de forma acentuada as palavras, com ênfase nas possíveis intenções das personagens, leitura expressiva por excelência, abre possibilidade de se levantar e gesticular.

- Leitura rápida: leitura similar à fala de um locutor de futebol (rádio), modo de ler as palavras ligeiramente.

- Leitura devagar: leitura silábica, em que se aproveita a articulação da boca, da língua e da face como um todo, trabalha com o grau de abertura das vogais, leitura lenta, no sentido estrito da palavra.

- Leitura rindo: leitura que faz do texto uma piada constante, palavras entrecortadas por risadas tímidas ou escandalosas, respiração audível, leitura risonha, engraçada.

- Leitura chorando: leitura chorosa, triste, melancólica.

- Leitura com sotaque: leitura que retoma os dialetos regionais, com a possibilidade de utilizar/conhecer a língua falada usada em outras localidades.

- Leitura cantando: leitura que faz do texto versos de uma canção, imprimem-se curvas melódicas, ritmos diversos.

- Leitura sussurrando: leitura em pequenos sopros, em tom baixo, as palavras se transformam em "segredos" que só podem ser ditos de forma muito cautelosa.

- Leitura gritando: leitura em tom alto, aos berros, expressão de emoções (raiva, desespero, animação, felicidade, êxtase etc.).

- Leitura com sono: leitura entrecortada por bocejos, voz cansada, pausas que sinalizam sonolência.

Coletivamente, sugerir aos alunos que distribuam um tipo de leitura para cada personagem e, voluntariamente, decidam qual personagem da peça desejam fazer a leitura das falas, em voz alta.

Fonte: Elaborado pelos autores.

3 A apresentação dessas nomenclaturas, bem como as explicações que se seguem a cada tipo de leitura dramática, reportam nossa experiência em oficinas de teatro já ministradas para atores e não-atores, em contextos variados, dentro e fora do ambiente escolar.

\section{LINHA DÁGUA}


A sugestão dessa atividade decorre do entendimento de que, ao oralizar o texto dramático e dar voz às personagens, interpretando-as de modo diversificado, o aluno-leitor se desdobra em aluno-orador, operando concretamente com a leitura da obra, lançando mão de recursos prosódicos, tais como entonação, ritmo, volume, entre outros. Além disso, a tomada de decisão de distinguir os modos de leitura das falas das personagens pode facilitar a compreensão do início da obra, em que a trama é instaurada com a participação de muitas vozes, entremeadas por objetivos específicos de cada personagem.

Para o trabalho de leitura do Ato II da peça, promovemos uma atividade arraigada no processo de construção da personagem, vastamente divulgado pelo método do ator e diretor russo Stanislavski (2001 [1936]). No Quadro 4, a seguir, apresentamos a proposta, de certo modo desafiadora, do ponto de vista das competências requeridas para a ação sugerida: memorizar falas, realizar performance, por exemplo.

Quadro 4. Atividade de Leitura do Ato II

\section{CONSTRUÇÃO DE PERSONAGEM}

Separar os alunos em grupos. Orientar que façam a leitura do Ato II, em busca, especificamente, de expressões utilizadas para mencionar a personagem Catarina ao longo dessas cenas. Neste ato, há dois momentos em que tal caracterização ocorre: o primeiro deles, no conflito entre as irmãs e na intervenção do pai; o segundo, na apresentação de Catarina a Petrúquio. Em ambos, há a recorrência de termos depreciativos ou ironicamente elogiosos, tais como: "indomada", "irmãzinha", "insana", "monstro", "incontrolável", "inútil”, "antipática", "rabugenta", "agressiva", "afetuosa”, "graciosa", "medusa", "serpente”, “inesquecível”, “orgulhosa", "desagradável”, “selvagem”, “zangada", "arredia", "nojenta", "bruta”, “empedernida”, “emburrada”, “divertida”, “bem-educada”, "doce”, "enfezada" e "brincalhona". Feito o levantamento lexical, pedir para que discutam como essa personagem poderia ser interpretada no palco, a partir da caracterização indicada no texto escrito. Recorrer, para tanto, à técnica teatral, denominada ficha da personagem ${ }^{4}$, e convidar os alunos a responderem: "Como seria sua postura corporal, o tom de voz, as expressões faciais? Catarina teria algum vício ou cacoete? De que modo ela poderia gesticular? Como seria o seu caminhar?" etc. Propor que um dos alunos de cada grupo assuma o papel de Catarina, memorizando livremente duas ou três falas e que os demais alunos do grupo orientem e auxiliem no processo de ensaio. Ao final da preparação, solicitar que os alunos apresentem ao restante da turma a personagem, a fim de comparar as diferentes construções. Para tanto, dirigir as ações evocadas pelas falas selecionadas, orientando os alunos-Catarina à intencionalidade requerida: "Catarina falaria desse modo? Se portaria dessa forma?" etc.

Fonte: Elaborado pelos autores.

4 No universo teatral, essa técnica é comumente empregada no início da montagem de um espetáculo, no chamado "trabalho de mesa", em que os atores se reúnem e realizam um levantamento de elementos dados $a$ priori pelo autor, como pontapé inicial para a construção de suas personagens.

\section{LINHA DÁGUA}


Entendemos que, ao assumir tal performance, o aluno-ator pode vivenciar uma particularidade do texto dramático, corroborada por Stanislavski (2001 [1936], p. 43), para quem é preciso viver a personagem, "experimentando sentimentos que lhe sejam análogos"; tal tarefa, reiteramos, exige um desempenho complexo, mas se trata de uma atividade envolvente e desafiadora.

Avançamos à leitura do Ato III da peça com a proposta de uma atividade que remete à função de um dos envolvidos na produção de um espetáculo teatral, a saber: o figurinista, aquele responsável pela indumentária dos atores. $\mathrm{Na}$ encenação, o figurino tem papel fundamental, tornando-se "a segunda pele do ator", caracterizando-o e vestindo, literalmente, o ator de acordo com a verossimilhança de uma condição ou situação provocada pela cena (PAVIS, 2008, p. 168). Tal atividade é descrita no Quadro 5, a seguir.

Quadro 5. Atividade de Leitura do Ato III

\section{PRODUÇÃO DE FIGURINO}

Antecipadamente, orientar que os alunos tragam das suas casas, cada um, uma peça de roupa variada (masculina, feminina, grande, pequena, colorida, rasgada, velha etc.), um acessório (colar, pulseira, chapéu, calçado etc.) e um objeto aleatório (flor artificial, brinquedo, utensílio de cozinha etc.). No dia da aplicação, reunir e expor todos os materiais e realizar a leitura da rubrica que introduz e caracteriza a personagem Petrúquio na cena do casamento com Catarina:

Petrúquio entra vestindo roupas gastas, rasgadas, manchadas, que não combinam entre si, com franjas, babados, flores de pano e outros enfeites, com luvas e botas, cada uma de um modelo e cor, um chapéu enorme cheio de penas e plumas, parecendo ao mesmo tempo maluco, palhaço e mendigo. Grúmio o acompanha (SHAKESPEARE, 2013, p. 68).

Separar os alunos em trios e, de posse dos objetos, determinar um tempo para que caracterizem um dos colegas, conforme Petrúquio é descrito pelo dramaturgo (na rubrica anterior) e, também, de acordo com o que as demais personagens que participam da cena veem e que, de modo gradativo, verbalizam: "trajes extravagantes", "maltrapilho", "deselegante", "desrespeitoso", "extrapolado", "bizarro", "coberto de farrapos", "trapos", "andrajos", "rotos, rasgados", "encardidos, manchados", "aviltantes, repugnantes", "exótico", "esdrúxulo", "estapafúrdio" e "espiclondrífico". Ao final do tempo disponibilizado, solicitar que o aluno-Petrúquio desfile pela sala enquanto os alunos-figurinistas explicam o trabalho que realizaram e o que os motivaram nas escolhas dos adereços. Questionar os alunos quanto às implicações cênicas e narrativas desse figurino em vista da ocasião, analisando a displicência de Petrúquio ao se vestir com uma indumentária que representa o sentimento da personagem naquele momento.

Fonte: Elaborado pelos autores.

A atividade permite promover um engajamento do aluno-figurinista que, em equipe, pode extrapolar a leitura das páginas do livro, colocando-o à cena, na engrenagem de coconstrução do espetáculo, dando vida à personagem, naquela situação específica,

\section{LINHA D'́GUA}


materializando-a. Os processos requeridos nessa atividade (levar peça de roupa para escola, selecionar itens para trajar o colega, vestir o colega, desfilar como Petrúquio, por exemplo) são verdadeiramente multimodais, além de levarem o aluno à ação e promoverem a sua interação com a leitura da obra.

Dando continuidade à leitura do Ato IV da peça, elegemos as rubricas cênicas como mobilizadoras de uma possibilidade de encenação, desafiando alunos-leitores a figurarem como alunos-atores, alunos-diretores, alunos-cenógrafos, alunos-contrarregras e alunossonoplastas. A marcação das cenas no palco condiz com uma espécie de "coreografia do movimento da cena", isto é, a maneira como os atores podem movimentar-se no espaço determinado como cenário da peça, o modo como podem oralizar o texto e, enquanto oralizam, como agem (SPOLIN, 2010). No Quadro 6, a seguir, sugerimos uma atividade que se propõe a incluir os diversos participantes da maquinaria teatral.

Quadro 6. Atividade de Leitura do Ato IV

\section{DIREÇ̃̃O DE CENA}

Para a encenação da Cena I do Ato IV da peça, dividir os alunos em oito atores, um diretor e os demais em cenógrafos, contrarregras e sonoplastas. Fazer, inicialmente, a leitura de todas as rubricas dessa cena:

Som de chuva. Petrúquio entra puxando Catarina. Os dois estão com as roupas sujas de lama. [...] Catarina se recusa a continuar andando. [...] Petrúquio puxa Catarina, que vai chorando. Eles saem. [...] Trânio entra na frente do palco. Enquanto ele fala, atrás dele é armada a casa de Petrúquio. [...] Entra Nicolas, segundo criado de Petrúquio. [...] Entra Natanael, José e Felipe, os outros três criados. [...] Entram Petrúquio e Catarina, que olha em volta, não gostando de nada. Os criados olham para eles, assustados. [...] Catarina senta-se à mesa com seis cadeiras, os únicos móveis da sala. [...] Os outros criados vão correndo para a cozinha. [...] Os criados entram com o jantar. [...] Nicolas traz uma jarra com água. Petrúquio pega com truculência e derruba boa parte. [...] Catarina vai pegar a jarra, mas Petrúquio pega antes e atira toda a água em Nicolas. [...] Ele a leva para fora, quase arrastada. Trânio entra na frente do palco. [...] Os criados estão dormindo cada um em uma cadeira. Grúmio entra e acorda Nicolas. [...] Gritos de Petrúquio fora de cena. Ele entra, de roupão, puxando Catarina, que está de penhoar. Petrúquio traz dois lençóis e uma colcha. [...] Os outros criados acordam, pulam das cadeiras e saem. Catarina senta-se e adormece. [...] Os criados entram com um ou dois travesseiros. [...] Ele vai pegando os travesseiros e jogando nos criados, e acaba fazendo uma guerra de travesseiros com eles. Grúmio senta-se e balança a cabeça. Catarina adormece em pé. (SHAKESPEARE, 2013, p. 78-84)

Orientar que, a partir das rubricas disponíveis no texto escrito, o aluno-diretor deverá organizar a encenação. Enquanto isso, propor que os alunos-sonoplastas produzam, oralmente, com o próprio corpo ou utilizando objetos da sala de aula, os efeitos sonoros descritos na cena (sacudir uma folha de caderno para simular o som da chuva, por exemplo); de modo similar, de posse dos objetos da sala de

\section{LINHA DÁGUA}


aula, os alunos-cenógrafos organizarão o cenário (carteiras e cadeiras da sala de aula), enquanto os alunos-contrarregras entrarão e sairão com os objetos de cena (estojo como jarra, mochilas como travesseiros). Aos alunos-atores caberá movimentar-se na cena sem, no entanto, usar a fala.

Fonte: Elaborado pelos autores.

Conforme entendemos, a arte teatral edifica-se em um trabalho de equipe; quando o texto vai à cena, instaura-se uma engrenagem complexa. Em razão disso, julgamos pertinente que, em uma proposta de leitura da obra de teatro na escola, os alunos possam exaurir as possibilidades da materialidade escrita, convocando a sua manifestação, disponibilizando-se para a ação cênica multimodal. No movimento didático promovido pela atividade Direção de cena, o professor assume, também e coletivamente, a função do aluno-diretor, mediando as suas decisões, orientando-as, encorajando-as e validando-as.

Para encerrar a leitura da obra, o Ato $\mathrm{V}$, formulamos uma atividade de produção textual escrita de uma cena complementar. Neste ponto, a Leitura encaminha-se para a Interpretação, solicitando ao aluno que, efetivamente, leia o ato, mas que elabore a sua continuidade a partir dos sentidos atribuídos no Momento interior de leitura. No Quadro 7, a seguir, descrevemos a atividade, que busca a leitura específica do trecho e também global da peça teatral na materialização do que significaram durante a leitura.

Quadro 7. Atividade de Leitura do Ato V

\section{PRODUÇÃO ESCRITA DE CENA}

Debater com os alunos se Catarina foi realmente "domada". Para tanto, dar ênfase à fala inicial de Trânio e ao diálogo final entre Grêmio e Lucêncio. No primeiro caso, a personagem define a peça como uma "trama cheia de pessoas que fingem ser outra pessoa", em metalinguagem implícita acerca do texto dramático, "ou fingem ser de um jeito e depois fingem que passaram a ser de outro" (SHAKESPEARE, 2013, p. 22). Naquele primeiro, sustenta-se a questão de se, de fato, Catarina mudou e se adequou aos padrões que lhes são impostos, ou não: "GRÊMIO - Ele cumpriu a promessa de domar a megera. / LUCÊNCIO -Só resta saber quem foi que domou quem!” (SHAKESPEARE, 2013, p. 120). Realizada essa leitura, orientar que os alunos redijam uma cena final entre Catarina e Petrúquio, apresentando qual é a compreensão que têm da resposta. Para tanto, instruir que a apresentem como a terceira cena do quinto ato e desenvolvam um diálogo que deixe implícito se a mudança de Catarina foi verdadeira ou não, utilizando, para tanto, rubricas pertinentes a esse entendimento.

Fonte: Elaborado pelos autores.

\section{LINHA DÁGUA}


Nossa proposta de atividade intitulada Produção escrita de cena convoca o aluno a assumir o papel de dramaturgo, ao escrever possibilidades de projeção de um diálogo no palco, acrescentando à fala de cada personagem uma rubrica, a partir do uso de adjetivos, de advérbios e das respectivas locuções que estejam correlacionadas ao clima que a cena evoca, respeitando, também, o perfil de cada personagem e a coerência em relação à estória apresentada.

A atividade propõe a reflexão em torno da palavra escrita, ao projetar a possibilidade da sua interpretação no palco. Da correlação entre ensino de língua materna e oralidade, é válido mencionar o trabalho das estudiosas da linguagem Fávero, Andrade e Aquino (2002). As autoras buscam promover a discussão da fala como modalidade a ser ensinada junto à modalidade escrita, dado que fala e escrita mantêm entre si relações mútuas e intercambiáveis. Em nosso caso, ao produzir uma nova cena, o aluno-dramaturgo estabelece contato com o modo escritural (escrevendo diálogo, inserindo rubricas), com vistas à oralidade e, por assim dizer, à multimodalidade.

De modo geral, as atividades criadas para a Leitura não só rejeitam a concepção da leitura literária como ato autônomo, individual e instintivo, mas também possibilitam a intervenção direta, segmentada e diagnóstica do professor, que lhe permita orientar o processo de leitura em sua complexidade. Nossa proposta prevê que o aluno tenha o seu repertório de leitura do texto (e da linguagem) teatral ampliado, ao analisar os recursos estilísticos e expressivos. Entendemos que essas atividades podem ser realizadas de uma forma coletiva, interativa e multimodal, respeitando a obra na sua integridade artística e avançando quanto à sua apreciação literária.

\subsection{Interpretação}

Neste último passo, a Interpretação, propomos uma atividade que permita a discussão com os colegas e a apresentação das impressões e das reflexões individuais dos alunos ao coletivo da sala de aula. Desse modo, selecionamos o gênero cartaz de divulgação a ser produzido por ter relação direta com o campo teatral e por permitir a expressão de uma nova modalidade de leitura, a visual. Assim, o aluno-produtor envolve-se em uma ação dupla: o produtor teatral e o produtor textual.

Fazemos, aqui, uma ressalva: a produção do gênero cartaz de divulgação, por si, demanda uma sequência de ensino que envolva compreensão, sistematização e produção, sob a orientação de outras teorias. Assim, entendemos que esta atividade poderia privilegiar, também, outros gêneros: o comentário, a resenha crítica, o artigo de opinião, o conto etc; além disso, poderia ser inserido o estudo de outros conteúdos gramaticais e textuais, por exemplo, pertinentes ao gênero selecionado. Entretanto, nosso olhar reserva-se a cumprir aquilo que a Sequência sugere. No Quadro 8, a seguir, orientamos a elaboração desta atividade.

\section{LINHA D'ÁGUA}


Quadro 8. Atividade de Interpretação

\section{PRODUÇÃO DE CARTAZ DE DIVULGAÇÃO}

Com os alunos em grupos, propor a produção de um cartaz de divulgação que traduza a compreensão global que tiveram da peça. Indicar a realização de uma nova pesquisa bibliográfica acerca das características do gênero, buscando também exemplos de cartazes para se inspirarem; depois, encaminhar o uso de cartolina, de materiais (revistas, impressões, canetas, tinta etc.) e de técnicas diversas (desenho, pintura, colagem etc.) da escolha dos grupos para a produção do cartaz. Neste processo, os alunos deverão traduzir sua compreensão da peça teatral por meio de elementos imagéticos. Após a produção do cartaz, pedir aos grupos que fiquem dispostos em roda, para exposição e análise. O professor, nesse momento, pode assumir a função de mediador das apresentações e dos debates, questionando, instigando e relacionando as falas dos alunos.

Fonte: Elaborado pelos autores.

A Interpretação enquanto passo da Sequência básica do letramento literário é o momento em que a leitura ganha significado social. A escritura de uma nova cena, descrita no passo anterior, já oportuniza aos alunos ressignificarem os sentidos que criaram em suas leituras (Momento interior), ao confrontarem o contexto histórico em que leram a peça com aquele em que o texto foi publicado. Ao produzirem e socializarem os cartazes, projetam, também, as suas leituras para a comunidade, compartilhando-as entre os colegas de sala e inferindo quais seriam as possíveis apreensões do texto por outros leitores (Momento externo).

\section{Conclusão}

Este artigo propôs-se a apresentar uma experiência múltipla com a linguagem. Do escritural ao multimodal, entrecruzando a leitura literária à leitura dramática, no ponto em que ambas consideram a leitura a partir de suas três instâncias: a obra, o autor e o leitor.

Ao apresentar a sequência para o (multi)letramento de $A$ megera domada (2013), a ser aplicada no $9^{\circ}$ ano do ensino fundamental, discutimos a ideia de que o texto dramático pode instaurar o trabalho com competências linguísticas, comunicativas e expressivas, considerando, para isso, tanto o aluno-leitor como também aluno-jogador, aluno-espectador, aluno-orador, aluno-ator, aluno-figurinista, aluno-cenógrafo, aluno-contrarregra, aluno-sonoplasta, alunodiretor, aluno-dramaturgo e aluno-produtor. Essa reconfiguração pressupõe um professor ativo no processo de mediação desta obra, desafiando os alunos e se desafiando a ocupar lugares também diversos.

O tratamento literário que se deu no ensino dessa obra teatral ganhou novos contornos ao sinalizar atividades didáticas que propusessem práticas multimodais, conduzindo a uma vivência dramatúrgica completa. Embora partam de lugares teóricos diferentes, os pressupostos para o ensino de leitura nas aulas de língua portuguesa, quando correlacionados, podem gerar

\section{LINHA D'́GUA}


novos elementos formadores. Ao professor, cabe o papel de mediar, de desafiar, de orientar, de provocar. Ao aluno, o de agir e de assumir posições leitoras que também o convoquem a jogar, a pesquisar, a ler, a dramatizar, a dirigir e a escrever.

Assim, o encontro teórico por nós promovido neste artigo entre letramento literário e multimodalidade revela-se pertinente no ensino de língua materna, do mesmo modo como o sugeriu Iturbe (2007, p. 9-10), ao indicar:

Aspectos tais como a expressão oral em todas as suas dimensões (vocalização, dicção, tom, entonação, riqueza expressiva, modulação), expressão escrita, estabelecimento de diálogos (ortografia, especialmente pontuação), descrição de cenários, movimentos e personagens concentram os esforços da disciplina de Língua, fazendo dela uma matéria essencial para o desenvolvimento da arte, da comunicação e da informação.

Entendemos, por fim, que a sala de aula constitui um laboratório em que é possível ousar, criar, reinventar e experimentar as teorias de ensino, a fim de cumprir com o objetivo máximo da aprendizagem: a formação do aluno.

\section{Referências}

CHACRA, S. Natureza e sentido da improvisação teatral. 2. ed. São Paulo: Perspectiva, 2010. COLOMER, T. Andar entre livros: a leitura literária na escola. Tradução por Laura Sandroni. São Paulo: Global, 2018 [2007].

COPE, B.; KALANTZIS, M. (org.). Multiliteracies: Literacy Learning and the Design of Social Futures. London/New York: Routledge, 2000.

COSSON, R. Letramento literário: teoria e prática. 2. ed. São Paulo: Contexto, 2019 [2006].

COSSON, R. Paradigmas do ensino de literatura. São Paulo: Contexto, 2020.

FÁVERO, L. L.; ANDRADE, M. L. C. V. O.; AQUINO, Z. G. O. Oralidade e escrita: perspectivas para o ensino de língua materna. 3. ed. São Paulo: Cortez, 2002.

GIL, A. C. Como elaborar projetos de pesquisa. 4. ed. São Paulo: Atlas, 2002 [1987].

HELBO, A. Teoría del espetáculo. El paradigma espetacular. Buenos Aires: Galerna, 1989.

ITURBE, T. Teatro para representar na Escola. Tradução por Silvia Massimini. São Paulo: Madras, 2007.

JEWITT, C. Multimodality and literacy in school classrooms. Review of Research in Education, v. 32, n. 1, p. 241-267, 2008.

KLEIMAN, A. B. Letramento na contemporaneidade. Bakhtiniana. São Paulo, 9 (2), ago./dez., 2014, p.72-91.

MAREGA, L. M. P. A palavra em cena: o texto dramático no ensino de língua portuguesa. 2015. Tese (Doutorado em Filologia e Língua Portuguesa) - Faculdade de Filosofia, Letras e Ciências Humanas, Universidade de São Paulo, São Paulo, 2015.

\section{LINHA D'́GUA}


MELLO, R. Teatro, gênero e análise do discurso. In: MACHADO, I. L. M.; MELLO, R. (org.). Gêneros: reflexões em Análise do Discurso. Belo Horizonte: NAD/FALE/UFMG, 2004, p. 87106.

PAVIS, P. Dicionário de teatro. 3. ed. Tradução por Jacó Guinsburg e Maria Lúcia Pereira. São Paulo: Perspectiva, 2008.

PEIXOTO, F. O que é teatro. São Paulo: Brasiliense, 1986.

ROJO, R. H. R; BARBOSA, J.P. Hipermodernidade, multiletramentos e gêneros discursivos. São Paulo: Parábola, 2015.

ROSENFELD, A. Prismas do teatro. São Paulo: Perspectiva, 1993.

RYNGAERT, J. P. Introdução à análise do teatro: leitura e crítica. Tradução por Paulo Neves. Rev. Trad. Monica Stahel. São Paulo: Martins Fontes, 1995.

SHAKESPEARE, W. A megera domada. Tradução por Flavio de Souza. São Paulo: FTD, 2013. SPOLIN, V. Jogos teatrais na sala de aula: um manual para o professor. 2. ed. São Paulo: Perspectiva, 2010.

STANISLAVSKI, C. A preparação do Ator. Tradução por Pontes de Paula Lima. Rio de Janeiro: Civilização Brasileira, 2001 [1936].

UBERSFELD, A. Para ler o teatro. Tradução por José Simões. São Paulo: Perspectiva, 2010.

Recebido: 30/04/2021.

Aprovado: 02/08/2021. 